\title{
Kekerasan dalam Rumah Tangga: Perspektif Psikologis dan Edukatif
}

\section{Rochmat Wahab}

Every family hopes to build harmony family, happy family, and mutual loving each others. In fact, there are several violences that happen in family life either physically, $p$ sychologically, sexually, or emotionally. The violence in family because of internal and extemal factors either individually or collectively. In particular in the age of information nowadays the violence cultures emerges by information that producing by media, both printed media and electronic media. The condition tends to influence the development of children, so that they can not grow naturally, they can not reach high score in their school. Hence, it needs to be conducted psychologically, educatively, preventively, and curatively toward the cases that happen in family life, especially the victims and society in general.

Kata kunci: kekerasan, rumah tangga, psikologis, budaya.

Dada dasarnya setiap keluarga ingin membangun keluarga bahagia dan penuh rasa saling mencintai baik secara lahir maupun batin, dengan kata lain bahwa setiap keluarga sungguh menghendaki dapat membangun keluarga harmoni dan bahagia yang sering disebut keluarga sakinah, mawaddah wa rahmah. Pada kenyataannya bahwa tidak semua keluarga dapat berjalan mulus dalam mengarungi hidupnya, karena dalam keluarga tidak sepenuhnya dapat dirasakan kebahagiaan dan saling mencintai dan menyayangi, melainkan terdapat rasa ketidaknyamanan, tertekan, atau kesedihan dan saling takut dan benci di antara sesamanya. Hal ini diindikasikan dengan masih dijumpainya pada sejumlah rumah tangga yang bermasalah, bahkan terjadi berbagai ragam kekerasan dalam rumah tangga (KDRT). Ironisnya jumlah kekerasan yang terjadi semakin hari semakin meningkat baik secara kuantitatif maupun kualitatif (Lihat tabel di bawah ini)

Jumlah Kasus Kekerasan yang terjadi dalam Rumah Tangga/Domestik di LBH APIK JAKARTA Tahun 1998 - 2002

\begin{tabular}{|l|c|c|c|c|c|}
\hline Jenis Kasus & 1998 & 1999 & 2000 & 2001 & 2002 \\
\hline Kekerasan Fisik & 33 & 52 & 69 & 82 & 86 \\
\hline Kekerasan Psikis & 119 & 122 & 174 & 76 & 250 \\
\hline Kekerasan Ekonomi & 58 & 58 & 85 & 16 & 135 \\
\hline Kekerasan Seksual & 3 & 15 & 1 & 0 & 7 \\
\hline Perkosaan & 1 & 10 & 0 & 0 & 0 \\
\hline Pelecehan Seksual & 2 & 5 & 1 & 0 & 0 \\
\hline Ingkar Janji & 0 & 0 & 3 & 14 & 5 \\
\hline Dating Violence & 0 & 0 & 0 & 0 & 7 \\
\hline Penganiayaan Anak & 0 & 0 & 0 & 0 & 1 \\
\hline
\end{tabular}


Data tersebut mengindikasikan bahwa ada kecenderungan terjadi peningkátan KDRT di Jakarta; baik secara kuantitatif maupun kualitatif, bahḱan di Indoniesia. Almira At-Thahirah (2006) menjelaskan bahwa sekitar 24 juta perempuan dari 217 juta penduduk Indonesia terutama di pedesaan mengakui pernah mengalami kekerasan dan yang terbesar adalah KDRT. Komnas perempuan pada tahun 2001 melakukan survei pada 14 daerah di Indonesia (Aceh, Palembang, Jambi, Bengkulu, Jakarta, Jawa Barat, Jawa Tengah, Yogyakarta, Jawa Timur, Kalimantan Barat, Maluku, Sulawesi Utara, Sulawesi Selatan, NTT) menunjukkan bahwa kaum perempuan paling banyak mengalami kekerasan dan penganiayaan oleh orang-orang terdekatnya serta tindak perkosaan di lingkungan komunitasnya sendiri. Selain daripada itu terdapat $60 \%$ kekerasan terhadap anak dilakukan oleh orangtua mereka! (Seto Mulyadi, Komnas Anak). (Zastrow \& Bowker (1984) menegaskan bahwa jumlah ini memang tidak sebanyak angka KDRT di AS yang melebihi dari $50 \%$ dari keluarga Amerika Serikat mengalami KDRT. Ada dua faktor yang menyebabkan timbulnya KDRT, yaitu faktor internal dan eksternal. Secara internal, KDRT dapat terjadi sebagai akibat dari semakin lemahnya kemampuan adaptasi setiap anggota keluarga di antara sesamanya, sehingga setiap anggota keluarga yang memiliki kekuasaan dan kekuatan cenderung bertindak deterministik dan eksploitatif terhadap anggota keluarga yang lemah. Secara eksternal, KDRT muncul sebagai akibat dari intervensi lingkungan di luar keluarga yang secara langsung atau tidak langsung mempengaruhi sikap anggota keluarga, terutama orangtua atau kepala keluarga, yang terwujuud dalam perlakuan eksploitatif terhadap anggota keluarga yang sering kali ditampakkan dalam pemberian hukuman fisik dan psikis yang traumatik baik kepada anaknya, maupun pasangannya.

KDRT dengan alasan apapun dari waktu ke waktu akan berdampak terhadap keutuhan keluarga, yang pada akhimya bisa membuat keluarga berantakan. Jika kondisinya demikian, yang paling banyak mengalami kerugian adalah anak-anaknya terlebih bagi masa depannya. Karena itulah perlu terus diupayakan mencari jalan terbaik untuk menyelamatkan institusi keluarga dengan tetap memberikan perhatian yang memadai untuk penyelamatan terutama anggota keluarga, dan umumnya masyarakat sekitarnya.

Untuk lebih memahami persoalan KDRT, selanjutnya akan digali lebih jauh tentang makna KDRT, penyebab-penyebabnya, dampak KDRT, dan berbagai pendekatan untuk penanganannya.

\section{Makna Kekerasan Dalam Rumah Tangga (KDRT)}

Kekerasan Dalam Rumah Tangga (KDRT) dapat diartikan sebagai tindakan kekerasan yang dilakukan oleh seorang pengasuh, orangtua, atau pasangan. KDRT dapat ditunjukkan dalam berbagai bentuk, di antaranya: Kekerasan fisik, penggunaan kekuatan fisik; kekerasan seksual, setiap aktivitas seksual yang dipaksakan; kekerasan emosional, tindakan yang mencakup ancaman, kritik dan menjatuhkan yang terjadi terus menerus; dan mengendalikan untuk memperoleh uang dan menggunakannya.

Berdasarkan Undang-Undang No 23 tahun 2004 tentang PKDRT pada pasal 1 butir 1 menyebutkan bahwa Kekerasan dalam Rumah Tangga adalah setiap perbuatan terhadap seseorang terutama perempuan, yang berakibat timbulnya 
kesengsaraan atau penderitaan secara fisik, seksual, psikologis, dan/atau penelantaran rumah tangga termasuk ancaman untuk melakukan perbuatan, 'pemaksaan, atau perampasan kemerdekaan secara melawan hukum dalam lingkup rumah tangga. Demikian juga pada pasal 2 ayat 1 menyebutkan bahwa lingkup rumah tangga dalam Undang-Undang ini meliputi (a) Suami, isteri, dan anak (termasuk anak angkat dan anak tiri); (b) Orang-orang yang mempunyai hubungan keluarga dengan orang sebagaimana dimaksud dalam huruf a karena hubungan darah, perkawinan, persusuan, pengasuhan, dan perwalian, yang menetap dalam rumah tangga (mertua, menantu, ipar dan besan); dan/atau (c) Orang yang bekerja membantu rumah tangga dan menetap dalam rumah tangga tersebut (Pekerja Rumah Tangga).

Lau dan Kosberg, (1984) melalui studinya menegaskan bahwa ada empat tipe kekerasan, di antaranya: physical abuse, psychological abuse, material abuse or theft of money or personal property, dan violation of right. Berdasarkan studinya anak-anak yang menjadi korban KDRT cenderung memiliki ketidakberuntungan secara umum. Mereka cenderung menunjukkan tubuh yang lebih kecil, memiliki kekuatan yang lebih lemah, dan merasa tak berdaya terhadap tindakan agresif.

Lebih jauh lagi bentuk-bentuk KDRT dapat dijelaskan secara detil.

Pertama, kekerasan fisik adalah perbuatan yang mengakibatkan rasa sakit, jatuh sakit atau luka berat (Pasal 6). Adapun kekerasan fisik dapat diwujudkan dengan perilaku di antaranya: menampar, menggigit, memutar tangan, menikam, mencekek, membakar, menendang, mengancam dengan suatu benda atau senjata, dan membunuh. Perilaku ini sungguh membuat anak-anak menjadi trauma dalam hidupnya, sehingga mereka tidak merasa nyamiann dan aman.

Kedua, kekerasan psikis addah perbuatan yang mengakibatkan ketakutan, hilangnya rasa percaya diri, hilangnya kemampuan untuk bertindak, rasa tidak berdaya, dan/atau penderitaan psikis berat pada seseorang (pasal 7). Adapun tindakan kekerasan psikis dapat ditunjukkan dengan perilaku yang mengintimidasi dan menyiksa, memberikan ancaman kekerasan, mengüurung di rumah, penjagaan yang berlebihan, ancaman untuk melepaskan penjagaan anaknya, pemisahan, mencaci maki, dan penghinaan secara terus menerus.

Ketiga, kekerasan seksual adalah setiap perbuatan yang berupa pemaksaan hubungan seksual, pemaksaan hubungan seksual dengan cara tidak wajar dan/atau tidak disukai, pemaksaan hubungan seksual dengan orang lain untuk tujuan komersial dan/atau tujuan tertentu. Kekerasan seksual meliputi (pasal 8): (a) Pemaksaan hubungan seksual yang dilakukan terhadap orang yang menetap dalam lingkup rumah tangga tersebut; (b) Pemaksaan hubungan seksual terhadap salah seorang dalam lingkup rumah tangganya dengan orang lain untuk tujuan komersial dan/atau tujuan tertentu.

Keempat, penelantaran rumah tangga adalah seseorang yang menelantarkan orang dalam lingkup rumah tangganya, padahal menurut hukum yang berlaku baginya atau karena persetujuan atau perjanjian ia wajib memberikan kehidupan, perawatan, atau pemeliharaan kepada orang tersebut. Selain itu, penelantaran juga berlaku bagi setiap orang yang mengakibatkan ketergantungan ekonomi dengan cara membatasi dan/atau melarang untuk bekerja yang layak di dalam atau di luar numah sehingga.korban berada di bawah kendali orang tersebut (pasial 9). 
Penelantaran rumah tangga dapat dikatakan dengan kekerasan ekonomik yang dapat diindikasikan dengan perilaku di antaranya seperti: penolakan untuk memperoleh keuangan, penolakan untuk memberikan bantuan yang bersifat finansial, penolakan terhadap pemberian makan dan kebutuhan dasar, dan mengontrol pemerolehan layanan kesehatan, pekerjaan, dan sebagainya.

\section{Penyebab Terjadinya KDRT}

Zastrow \& Browker (1984) menyatakan bahwa ada tiga teori utama yang mampu menjelaskan terjadinya kekerasan, yaitu teori biologis, teori frustasi-agresi, dan teori kontrol. .

Pertama, teori biologis menjelaskan bahwa manusia, seperti juga hewan, memiliki suatu insting agresif yang sudah dibawa sejak lahir. Sigmund Freud menteorikan bahwa manusia mempunyai suatu keinginan akan kematian yang mengarahkan manusia-manusia itu untuk menikmati tindakan melukai dan membunuh orang lain dan dirinya sendiri. RobertArdery yang menyarankan bahwa manusia memiliki instink untuk menaklukkan dan mengontrol wilayah, yang sering mengarahkan pada perilaku konflik antar pribadi yang penuh kekerasan.

Konrad Lorenz menegaskan bahwa agresi dan kekerasan adalah sangat berguna untuk survive. Manusia dan hewan yang agresif lebih cocok untuk membuat keturunan dan survive, sementara itu manusia atau hewan yang kurang agresif memungkinkan untuk mati satu demi satu. Agresi pada hakekatnya membantu untuk menegakkan suatu sistem dominan, dengan demikian memberikan struktur dan stabilitas untuk kelompok.

Beberapa ahli teori biologis berhipotesis bahwa hormon sek pria menyebabkan perilaku yang lebih agresif. Di sisi lain, ahli teori belajar berteori bahwa perbedaan perilaku agresif terutama disebabkan oleh perbedaan sosialisasi terhadap pria dan wanita.

Kedua, teori frustasi-agresi menyatakan bahwa kekerasan sebagai suatu cara untuk mengurangi ketegangan yang dihasilkan situasi frustasi. Teori ini berasal dari suatu pendapat yang masuk akal bahwa seseorang yang frustasi sering menjadi terlibat dalam tindakan agresif. Orang frustasi sering menyerang sumber frustasinya atau memindahkan frustasinya ke orang lain. Misalnya, seorang remaja (teenager) yang diejek oleh orang lain mungkin membalas dendam, sama halnya seekor binatang kesayangan yang digoda. Seorang pengangguran yang tidak dapat mendapatkan pekerjaan mungkin memukul istri dan anak-anaknya.

Suatu persoalan penting dengan teori ini, bahwa teori ini tidak menjelaskan mengapa frustasi mengarahkan terjadinya tindakan kekerasan pada sejumlah orang, tidak pada orang lain. Diakui bahwa sebagian besar tindakan agresif dan kekerasan nampak tidak berkaitan dengan frustasi. Misalnya, seorang pembunuh profesional tidak harus menjadi frustasi untuk melakukan penyerangan.

Walaupun teori frustasi-agresi sebagian besar dikembangkan oleh para psikolog, beberapa sosiolog telah menerapkan teori untuk suatu kelompok besar. Mereka memperhatikan perkampungan miskin dan kotor di pusat kota dan dihuni oleh kaum. minoritas telah menunjukkan angka kekerasan yang tinggi. Mereka berpendapat bahwa kemiskinan, kekurangan kesempatan, dan ketidakadilan lainnya di wilayah ini sangat membuat frustasi penduduknya. Penduduk semua menginginkan semua banda yang mereka lihat dan dimiliki oleh orang lain, 
serta tak ada hak yang sah sedikitpun untuk menggunakannya. Akibatnya, mereka frustasi dan berusaha untuk menyerangnya. Teori ini memberikan penjelasan yang masuk akal terhadap angka kekarasan yang tinggi bagi penduduk minoritas.

Ketiga, teori ini menjelaskan bahwa orang-orang yang hubungannya dengan orang lain tidak memuaskan dan tidak tepat adalah mudah untuk terpaksa berbuat kekerasan ketika usaha-usahnya untuk berhubungan dengan orang lain menghadapi situasi frustasi. Teori ini berpegang bahwa orang-orang yang memiliki hubungan erat dengan orang lain yang sangat berarti cenderung lebih mampu dengan baik mengontrol dan mengendalikan perilakunya yang impulsif.

Travis Hirschi memberikan dukungan kepada teori ini melalu temuannya bahwa remaja putera yang memiliki sejarah prilaku agresif secara fisik cenderung tidak memiliki hubungan yang dekat dengan orang lain. Selain itu juga dinyatakan bahwa kekerasan mengalami jumlah yang lebih tinggi di antara para eks narapidana dan orang-orang lain yang terasingkan dari teman-teman dan keluarganya daripada orang-orang Amerika pada umumnya.

Setelah memperhatikan ketiga teori tersebut, kiranya variasi kekerasan di masyarakat untuk sementara ini disebabkan oleh tiga faktor tersebut. Bagaimana dengan penyebab munculnya KDRT, lebih khususnya di Indonesia. Menurut hemat saya, KDRT di Indonesia ternyata bukan sekedar masalah ketimpangan gender. $\mathrm{Hal}$ tersebut acapkali terjadi karena:

Kurang komunikasi, Ketidakharmonisan.

Alasan Ekonomi

Ketidakmampuan mengendalikan emosi
Ketidakmampuan mencari solusi masalah rumah tangga apapun; dan juga s.

- Kondisi mabuk karena minuman keras dan narkoba.

\section{Dampak KDRT terhadap Anak}

Marianne James, Senior Research pada Australian Institute of Criminology (1994), menegaskan bahwa KDRT memiliki dampak yang sangat berarti terhadap perilaku anak, baik berkenaan dengan kemampuan kognitif, kemampuan pemecahan masalah, maupun fungsi mengatási masalah dan emosi. Adapun dampak KDRT secara rinci akan dibahas berdasarkan tahapan perkembangannya sebagai berikut:

\section{Dampak terhadap Anak Berusia Bayi}

Usia bayi seringkali menunjukkan keterbatasannya dalam kaitannya dengan kemampuan kognitif dan beradaptasi. Jaffe dkk (1990) menyatakan bahwa anak bayi yang menyaksikan terjadinya kekerasan antara pasangan bapak dan ibu sering dicirikan dengan anak yang memiliki kesehatan yang buruk, kebiasaan tidur yang jelek, dan teriakan yang berlebihan. Bahkan kemungkinan juga anak-anak itu menunjukkan penderitaan yang serius. $\mathrm{Hal}$ inj berkonsekuensi logis terhadap kebutuhan dasarnya yang diperoleh dari.ibunya ketika mengalami gangguan yang sangat berarti. Kondisi ini pula berdampak lanjutan bagi ketidaknormalan dalam pertumbuhan dan perkembangannya yang seringkali diwujudkan dalam problem emosinya, bahkan sangat terkait dengan persoalan kelancaran dalam berkomunikasi. 


\section{Dampak terhadap anak kecil}

Dalam tahun kedua fase perkembangan, anak-anak mengembangkan upaya dasamya untuk mengaitkan penyebab perilaku dengan ekspresi emosinya. Penelitian Cummings dkk (1981) menilai terhadap ekspresi marah dan kasih sayang yang terjadi secara alamiah dan berpura-pura. Selanjutnya ditegaskan, bahwa ekspresi marah dapat menyebabkan bahaya atau kesulitan pada anak kecil. Kesulitan ini semakin menjadi lebih nampak, ketika ekspresi verbal dibarengi dengan serangan fisik oleh anggota keluarga lainnya. Bahkan banyak peneliti berhipotesis bahwa penampilan emosi yang kasar dapat mengancam rasa aman anak dalam kaitannya dengan lingkungan sosialnya.

Pada tahun ketiga ditemukan bahwa anak-anak yang merespon dalam interaksinya dengan kemarahan, maka yang ditimbulkannya adalah adanya sikap agresif terhadap teman sebayanya. Yang menarik bahwa anak laki-laki cenderung lebih agresif daripada anak-anak perempuan selama simulasi, sebaliknya anak perempuan cenderung lebih distress daripada anak lakilaki. Selanjutnya dapat dikemukakan pula bahwa dampak KDRT terhadap anak usia muda (anak kecil) sering digambarkan dengan problem perilaku, seperti seringnya sakit, 'memiliki rasa malu yang serius, memiliki self-esteem yang rendah, dan memilikimasalah selama dalam pengasuhan; terutama masalah sosial, misalnya: memukul, menggigit, dan suka mendebat.

\section{Dampak terhadap Anak Usia Pra Sekolah}

Cumming (1981) melakukan penelitian tentang KDRT terhadap anak-anak yang berusia TK, pra sekolah, sekitar 5 atau 6 tahun. Dilaporkannya bahwa Anak-anak yang memperoleh rasa distress pada usia sebelumnya dapat diidentifikasi tiga tipe reaksi perilaku. Pertama, 46\%-nya menunjukkan emosi negatif yang diwujudkan dengan perilaku marah yang diikuti setelahnya dengan rasa sedih dan berkeinginan untuk menghalangi atau campur tangan. Kedua, 17\%-nya tidak menunjukkan emosi, tetapi setelah itu mereka marah. Ketiga, lebih dari sepertiganya, menunjukkan perasaan emosional yang tinggi (baik positif maupun negatif) selama berargumentasi. Keempat, mereka bahagia, tetapi sebagian besar di antara mereka cenderung menunjukkan sikap agresif secara fisik dan verbal terhadap teman sebayanya.

Berdasarkan pemeriksaan terhadap 77 anak, Davis dan Carlson (1987) menemukan anak-anak TK yang menunjukkan perilaku reaksi agresif dan kesulitan makan pada pria lebih tinggi daripada wanita. Hughes (1988) melakukan penelitian terhadap ibu dan anak-anak yang usia TK dan non-TK, baik dari kelompok yang tidak menyaksikan KDRT maupun yang menyaksikan KDRT. Disimpulkan bahwa kelompok yang menyaksikan KDRT menunjukkan tingkat distress yang jauh lebih tinggi, dan kelompok anak-anak TK menunjukkan perilaku distres yang lebih tinggi daripada anak-anak non-TK.

De Lange (1986) melalui pengamatannya bahwa KDRT berdampak terhadap kompetensi perkembangan sosial-kognitif anak usia prasekolah. Ini dapat dijelaskan bahwa anak-anak prasekolah yang dipisahkan secara sosial dari teman sebayanya, bahkan tidak berkesempatan untuk berhubungan dengan kegiatan atau minat teman sebayanya juga, maká mereka cenderung memiliki beberapa masalah yang terkait dengan orang dewasa. 


\section{Dampak terhadap Anak Usia $S D$}

Jaffe dkk (1990) menyatakan bahwa pada usia SD, orangtua merupakan suatu model peran yang sangat berarti. Baik anak pria maupun wanita yang menyaksikan KDRT secara cepat belajar bahwa kekerasan adalah suatu cara yang paling tepat untuk menyelesaikan konflik dalam hubungan kemanusiaan. Mereka lebih mampu ,mengekspresikan ketakutan dan kecemasannya berkenaan dengan perilaku orangtuanya. Hughes (1986) menemukan bahwa anak-anak usia SD seringkali memiliki kesulitan tentang pekerjaan sekolahnya, yang diwujudkan dengan prestasi akademik yang jelek, tidak ingin pergi ke sekolah, dan kesulitan dalam konsentrasi.

Wolfe et.al, 1986: Jaffe et.al, 1986, Christopoulus et al, 1987 menguatkan melalui studinya, bahwa anak-anak dari keluarga yang mengalami kekerasan domistik cenderung memiliki problem perilaku lebih banyak dan kompetensi sosialnya lebih rendah daripada keluarga yang tidak mengalami kekerasan dalam rumah tangga.

Sementara studi yang dilakukan terhadap anak-anakAustralia, (Mathias et.al, 1995) sebanyak 22 anak dari usia 6 sd 11 tahun menunjukkan bahwa kelompok anakanak yang secara historis mengalami kekerasan dalam rumah tangganya cenderung mengalami problem perilaku pada tinggi batas ambang sampai tingkat berat, memiliki kecakapan adaptif di bawah rata-rata, memiliki kemampuan membaca di bawah usia kronologisnya, dan memiliki kecemasan pada tingkat menengah sampai dengan tingkat tinggi.

\section{Dampak terhadap Anak Remaja} $x=$

Pada usia ini biasanya kecakapan kognitif dan kemampuan beradaptasi telah mencapai suatu fase perkembangan yang meliputi dinamika keluarga dan jaringan sosial di luar rumah, seperti kelompok teman sebaya dan pengaruh sekolah. Dengan kata lain, anak-anak remaja sadar bahwa ada cara-cara yang berbeda dalam berpikir, merasa, dan berperilaku dalam kehidupan di dunia ini. Misalnya, studi Davis dan Carlson (1987) menyimpulkan, bahwa hidup dalam keluarga yang penuh kekarasan cenderung dapat meningkatkan kemungkinan menjadikan isteri yang tersiksa, sementara itu Hughes dan Barad (1983) mengemukakan dari hasil studinya, bahwa angka kejadian kekerasan yang tinggi dalam keluarga yang dilakukan oleh ayah cenderung dapat menimbulkan korban kekerasan, terutama anak-anaknya. Tetapi ditekankan pula oleh Rosenbaum dan O'Leary (1981), bahwa tidak semua anak yang hidup kesehariannya dalam hubungan yang penuh kekerasan akan mengulangi pengalaman itu. Artinya, bahwa seberat apapun kekerasan yang ada dalam rumah tangga, tidak sepenuhnya kekerasan itu berdampak kepada semua anak remaja, tergantung ketahanan mental dan kekuatan pribadi anak remaja tersebut.

Dari banyak penelitian menunjukkan bahwa konflik antar kedua orangtua yang disaksikan oleh anak-anaknya yang sudah remaja cenderung berdampak yang sangat berarti, terutama anak remaja pria cenderung lebih agresif, sebaliknya anak remaja wanita cenderung lebih dipresif.

\section{Upaya Penanganan KDRT}

Pada hakekatnya secara psikologis dan pedagogis ada dua pendekatan yáng 
dapat dilakukan untuk menangani KDRT, yaitu pendekatan kuratif dan preventif.

\section{Pendekatan Kuratif:}

a. Menyelenggaräkan pendidikan orangtua untuk dapat menerapkan cara mendidik dan memperlakukan anak-anaknya secara humanis.

b. Memberikan keterampilan tertentu kepada anggota keluarga untuk secepatnya melaporkan ke pihak lain yang diyakini sanggup mem-berikan pertolongan, jika sewaktu-waktu terjadi KDRT.

c. Mendidik anggota keluarga untuk menjaga diri dari perbuatan yang mengundang terjadinya KDRT.

d. Membangun kesadaran kepada semua anggota keluarga untuk takut kepada akibat yang ditimbulkan dari KDRT.

e. Membekali calon suami istri atau orangtua baru untuk menjamin kehidupan yang harmoni, damai, dan saling pengertian, sehingga dapat terhindar dari perilaku KDRT.

f. Melakukan filter terhadap media massa, baik cetak maupun elektronik, yang menampilkan informasi kekerasan.

g. Mendidik, mengasuh, dan memper-lakukan anak sesuai dengan jenis kelamin, kondisi, dan potensinya.

h. Menunjukkan rasa empati dan rasa peduli terhadap siapapun yang terkena KDRT, tanpa sedikitpun melemparkan kesalahan terhadap korban KDRT.

i. Mendorong dan menfasilitasi pengembangan masyarakat untuk lebih peduli dan responsif terhadap kasus-kasus KDRT yang ada di lingkungannya.

\section{Pendekatan Preventif:}

a. Memberikan sanksi secara edukatif kepada pelaku KDRT sesuai dengan jenis dan tingkat berat atau ringannya pelanggaran yang dilakukan, sehingga tidak hanya berarti bagi pelaku KDRT, tetapi juga bagi korban dan anggota masyarakat lainnya.

b. Memberikan incentive bagi setiap orang yang bejasa dalam mengurangi, mengeliminir, dan menghilangkan salah satu bentuk KDRT secara berarti, sehingga terjadi proses kehidupan yang tenang dan membahagiakan.

c. Menentukan pilihan model penanganan KDRT sesuai dengan kondisi korban KDRT dan nilai-nilai yang ditetapkan dalam keluarga, sehingga penyelesaiannya memiliki efektivitas yang tinggi.

d. Membawa korban KDRT ke dokter atau konselor untuk segera mendapatkan penanganan sejak dini, sehingga tidak terjadi luka dan trauma psikis sampai serius.

e. Menyelesaikan kasus-kasus KDRT yang dilandasi dengan kasih sayang dan keselamatan korban untuk masa depannya, sehingga tidak menimbulkan rasa dendam bagi pelakunya.

f. Mendorong pelaku KDRT untuk sesegera mungkin melakukan pertaubatan diri kepada Allah swt, akan kekeliruan dan kesalahan dalam berbuat kekerasan dalam rumah tangga, sehingga dapat menjamin rasa aman bagi semua anggota keluarga. 
Kekerasan dalam Rumah Tangga: Perspektif Psikologis dan...; Rochmat Wahab

g. Pemerintah perlu terus bertindak cepat dan tegas terhadap setiap praktek KDRT dengan mengacu pada UU tentang PKDRT, sehingga tidak berdampak jelek bagi kehidupan masyarakat.

Pilihan tindakan preventif dan kuratif yang tepat sangat tergantung pada kondisi riil KDRT, kemampuan dan kesanggupan anggota keluarga untuk keluar dari praketk KDRT, kepedulian masyarakat sekitarnya, serta ketegasan pemerintah menindak praktek KDRT yang terjadi di tengah-tengah masyarakat.

\section{Penutup}

Setiap keluarga pada awalnya selalu mendambakan kehidupan rumah tangga yang aman, nyaman, dan membahagiakan. Secara fitrah perbedaan individual dan lingkungan sosial budaya berpotensi untuk menimbulkan konflik. Bila konflik sekecil apapun tidak segera dapat diatasi, sangatlah mungkin berkembang menjadi KDRT. Kejadian KDRT dapat terwujud dalam bentuk yang ringan sampai berat, bahkan dapat menimbulkan korban kematian, sesuatu yang seharusnya dihindari.

Untuk dapat menyikapi KDRT secara efektif, perlu sekali setiap anggota keluarga memiliki kemampuan dan keterampilan mengatasi KDRT, sehingga tidak menimbulkan pengorbanan yang fatal. Tentu saja hal ini hanya bisa dilakukan bagi anggota keluarga yang sudah memiliki usia kematangan tertentu dan memiliki keberanian untuk bersikap dan bertindak. Sebaliknya jika anggota keluarga tidak memiliki daya dan kemampuan untuk menghadapi KDRT, secara proaktif masyarakat, para ahli, dan pemerintah perlu mengambil inisiatif untuk ikut serta dalam penanganan korban KDRT, sehingga dapat segera menyelamatkan dan menghindarkan anggota keluarga dari kejadian yangitidak diinginkan.

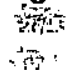

\section{Daftar Pustaka}

At-Thahirah, Almira, 2006, Kekerasan Rumah Tangga Produk Kapitalisme (Kritik Atas Persoalan KDRT), Bandung: UIN

Carlson, B.E. 1984, 'Children's observations of inter-parental violence' in: Battered Women and Their Families, ed. A.R. Roberts, Springer, New York.

Christopoulos, C., Cohn, D., Shaw, D., Joyce, S., Sullivan-Hanson, J., Kraft, S. and Emery, R. 1987, 'Children of abused women: adjustmenet at time of shelter residence', Joumal of the Marriage and the Family, vol. 49, pp. 611-19.

Cummings, E.M., Zahn-Waxler, C. and Radke-Yarrow, M. 1981, 'Young children's responses to expressions of anger and affection by others in the family', Child Development, vol.52, pp.1274-82.

Davis, L. and Carlson, B. 1987, 'Observation of spouse abuse: what happens to the children?', Journal of Interpersonal Violence vol.2, no.3, pp.27891.

Deaux, Kay \& Wrightsman, L.S. 1984, Social Psychology in the 80s, Fourth Edition, California: Brooks Cole Publishing Company.

De Lange, C.1986, 'The family place children's therapeutic program', Children's Today, pp.12-15. 
Topik: Budaya Kekerasan

Departemen Hukum dan Ham, 2004, Undang-Undang No 23 tahun 2004 tentang Penghapusan Kekerasan Dalam Rumah Tangga (PKDRT), Jakarta:

Eshlemen, Ross, J. 1988, The Family: An Introduction, Fifth Edition, Boston: Allen and Bacon

Hughes, H. 1986, Research with children in shelters: implications for clinical services, Children Today, vol.15, no.2, pp.21-5.

'Psychological and behavioural correlates of family violence in child witnesses and victims', American Journal of Orthopsychiatry, vol.58, no.1, pp.77-90.

Hughes, H. and Barad, S. 1983, 'Psychological functioning of children in a battered women's shelter: a preliminary investigation', American Journal of Orthopsychiatry, vol.53, no.3, pp.52531.
Jaffe, P., Wolfe, D., and Wilson, S.K. 1990, Children of Battered Women, Sage Publications, California.

Jaffe, P., Wolfe, D., Wilson, S. and Zak, L. 1986, 'Family violence and child adjustment: a comparative analysis of girls' and boys' behavioural symptoms', American Journal of Psychiatry, vol.143, no.1, pp.74-7.

Lembaga Bantuan Hukum untuk Peremouan dan Keadilan (LBHAPIK) Jakarta, (2002), Angka Kekerasan di Jakarta tahun 1998-2002, Jakarta: LBHAPIK

Mathias, J., Mertin, P. and Murray, B. 1995, 'The psychological functioning of children from backgrounds of domestic violence', Australian Psychologist, vol.30, no.1 (March).

Zastrow, Charles \& Bowker, Lee. 1984, Social Problems: Issues and Solutions, Chicago: Nelson-Hall 